
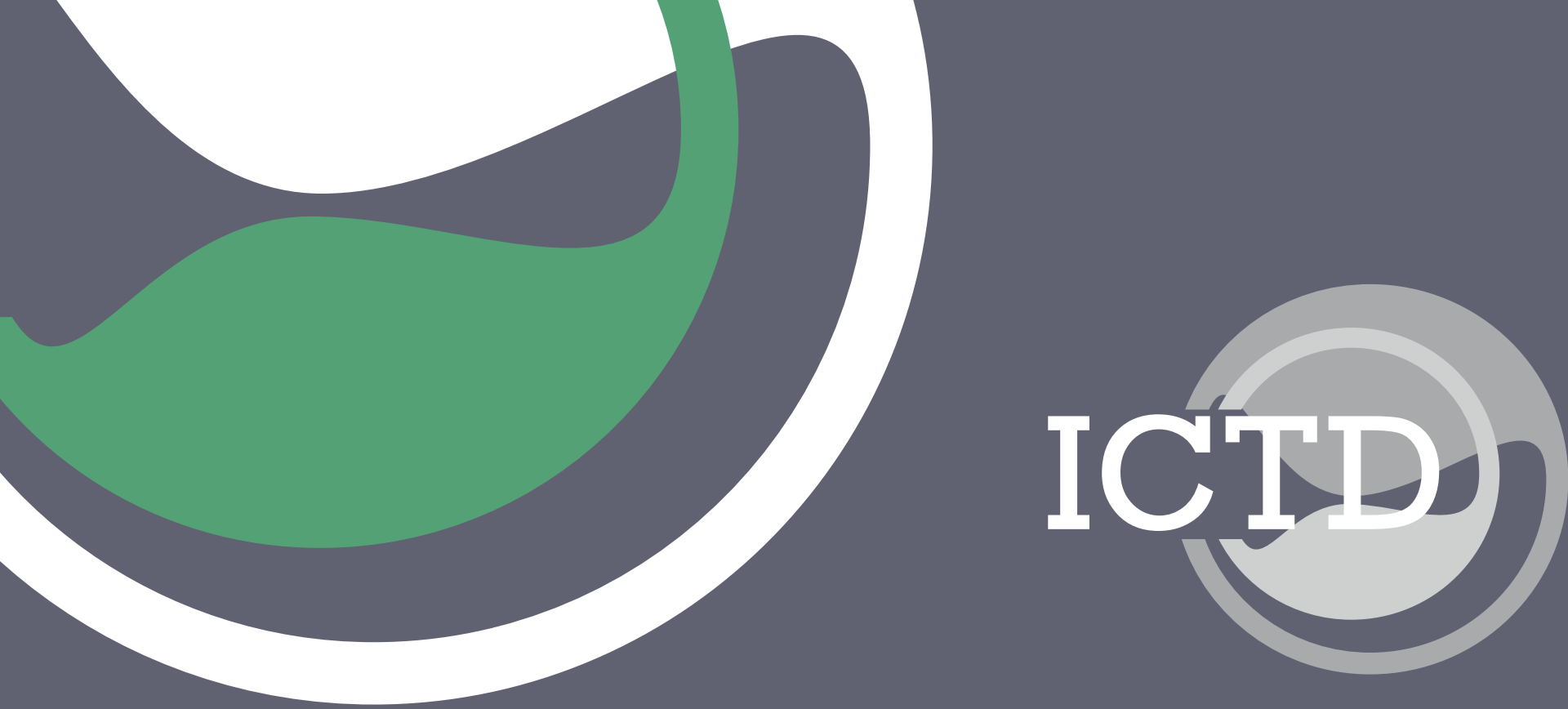

African Tax Administration Paper 26

Perception of Taxpayers and Tax Administrators Towards Value Added Withholding Tax in Zimbabwe

Simbarashe Hamudi

July 2021

BILL MELINDA

GATES foundation
(O) instifute of development studies
MR UKaid 
African Tax Administration Paper 26

Perception of Taxpayers and Tax Administrators Towards Value Added Withholding Tax in Zimbabwe

Simbarashe Hamudi

July 2021 
Perception of Taxpayers and Tax Administrators Towards Value Added Withholding Tax in Zimbabwe Simbarashe Hamudi

ICTD African Tax Administration Paper 26

First published by the Institute of Development Studies in July 2021

(C) Institute of Development Studies 2021

ISBN: [978-1-78118-826-2]

DOI: $\underline{10.19088 / I C T D .2021 .013}$

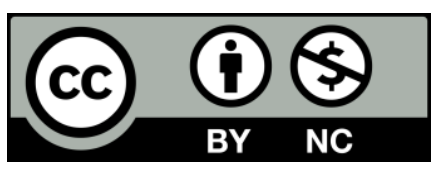

This is an Open Access paper distributed under the terms of the Creative Commons Attribution Non Commercial 4.0 International license, which permits downloading and sharing provided the original authors and source are credited - but the work is not used for commercial purposes. http://creativecommons.org/licenses/by-nc/4.0/legalcode

Available from:

The International Centre for Tax and Development at the Institute of Development Studies, Brighton BN1 9RE, UK

Tel: +44 (0) 1273606261

Email: info@ictd.ac

Web: www.ictd.ac/publication

Twitter: @ICTDTax

Facebook: www.facebook.com/ICTDtax

IDS is a charitable company limited by guarantee and registered in England

Charity Registration Number 306371

Charitable Company Number 877338 


\title{
Perception of Taxpayers and Tax Administrators Towards Value Added Withholding Tax in Zimbabwe
}

\author{
Simbarashe Hamudi
}

\section{Summary}

This study attempts to evaluate the perception of taxpayers and tax administrators towards value added withholding tax (VAWHT) policy in Zimbabwe, and to identify ways of improving VAWHT administration to increase collection of revenue from value added tax. Value added $\operatorname{tax}$ (VAT) is a key tax for generating revenue in Zimbabwe and all African states, and for financing the budget in African countries. However, the revenue authorities are not collecting large amounts of VAT for various reasons, including ineffective administration and tax evasion. This brings the question of reform of the VAT system to the forefront.

The value added withholding tax system brings the merits of tax deduction at source into VAT in order to curb tax non-compliance and tax evasion, and to generate more tax revenue. Both taxpayers and tax administrators perceive the VAWHT system as a way of considerably increasing revenue. However, it is not seen as an effective tax system, and is associated with high administrative costs, negatively impacting the cash flows of suppliers, and loss of customers and suppliers. Registered VAT operators have poor knowledge of the system.

To get more benefits from VAWHT, the government should:

- allow an exemption for compliant taxpayers, including VAT withholding agents;

- strengthen the refund system;

- educate and train suppliers on the benefits of the VAWHT system; and

- automate the VAWHT system.

Keywords: value added tax; withholding tax; tax administration; revenue and collection.

Simbarashe Hamudi is a transfer pricing manager at Tax Matrix in Harare, Zimbabwe. 


\section{Contents}

Summary 3

Acknowledgements 5

Acronyms

$1 \quad$ Introduction $\quad 6$

$2 \quad$ Literature review $\quad 7$

$3 \quad$ Zimbabwe $\quad 11$

$4 \quad$ Research methodology 12

$5 \quad$ Data presentation $\quad 13$

5.1 Responses from ZIMRA 13

5.2 Responses from value added withholding tax agents 15

$\begin{array}{lll}5.3 & \text { Responses from suppliers } & 16\end{array}$

$\begin{array}{lll}5.4 & \text { Zimbabwe VAT revenue performance } & 17\end{array}$

$6 \quad$ Summary of major findings 18

6.1 Conclusions 19

$\begin{array}{lll}6.2 & \text { Recommendations } & 20\end{array}$

$\begin{array}{ll}\text { References } & 21\end{array}$

Figures

Figure $1 \quad$ VAT contribution to total revenue in SSA and EU 7

Figure 2 Responses from ZIMRA revenue officers 14

Figure $3 \quad$ Responses from VAWHT agents 15

Figure $4 \quad$ Responses from suppliers 16

$\begin{array}{lll}\text { Figure } 5 & \text { VAT revenue performance } & 17\end{array}$ 


\section{Acknowledgements}

I am grateful to the International Centre for Tax and Development (ICTD) for providing the financial support that made this study possible. Special thanks go to Fabrizio Santoro, Kate Arnill Graham and all the reviewers of this paper for technical guidance and comments throughout the writing of this paper. I would also like to express my sincere gratitude to the staff of Zimbabwe Revenue Authority, value added withholding tax agents and all suppliers who took part in this study. Their knowledge and input greatly contributed to the quality and depth of the study and final paper. The author takes full responsibility for the content of this paper.

\section{Acronyms}

$\begin{array}{ll}\text { ATAF } & \text { Africa Tax Administration Forum } \\ \text { FIRS } & \text { Federal Inland Revenue Services } \\ \text { GST } & \text { Goods Sales Tax } \\ \text { KRA } & \text { Kenya Revenue Authority } \\ \text { ICTD } & \text { International Centre for Tax and Development } \\ \text { IMF } & \text { International Monetary Fund } \\ \text { OECD } & \text { Organisation for Economic Co-operation and Development } \\ \text { SSA } & \text { Sub-Saharan Africa } \\ \text { UN } & \text { United Nations } \\ \text { VAT } & \text { Value added tax } \\ \text { VAWHT } & \text { Value added withholding tax } \\ \text { ZRA } & \text { Zambia Revenue Authority } \\ \text { ZIMRA } & \text { Zimbabwe Revenue Authority }\end{array}$




\section{Introduction}

Value added tax is a key tax for generating revenue in Zimbabwe and all African states, and for financing the budget in African countries. VAT revenue has an essential role in budgetary policymaking. Every year revenue authorities are not collecting large amounts of VAT for various reasons, including ineffective administration and tax evasion. This brings the question of the reform of the VAT system to the forefront.

In Zimbabwe, attempts to improve VAT revenue collection have been made over several years. Hopes were pinned on the use of fiscalisation and audits of VAT refunds. ${ }^{1}$ However, traders continue to evade VAT - and this has led to the introduction of value added withholding tax to improve VAT revenue collection.

Value added withholding tax (VAWHT) ensures that non-compliant traders, particularly those in hard-to-tax sectors, are forced to pay at least some VAT. It is claimed that VAWHT provides a way of increasing VAT collection where administration is weak and attitudes to taxation are poor - particularly among smaller and medium clients, where the risk of noncompliance is considered to be high.

Tax revenue authorities implement VAWHT as a tax collection mechanism to enforce and reduce the time in which VAT is collected from certain taxpayers and specific economic sectors (KRA 2016). VAWHT is the application of a reverse charge mechanism on transactions carried out within a given tax jurisdiction. VAWHT systems typically oblige value added withholding tax agents, appointed by revenue authorities to collect VAWHT on behalf of the government, to withhold VAT charged to them by their suppliers when they pay their suppliers for taxable goods and services (ZRA 2018). Instead of paying VAT to their suppliers, VAWHT agents are required to remit the VAT revenue collected directly to the revenue authorities (FIRS 2018).

There are $78 \mathrm{VAWHT}$ agents in Zimbabwe. These are mainly mining companies - the large clients of ZIMRA and the biggest companies, and were appointed based on their high level of compliance and capability to administer VAWHT. Some VAWHT agents employ competent tax practitioners.

The basis for using VAWHT is that unregistered traders, particularly those in the informal sector and hard-to-tax sectors, will have to pay some VAT revenue to the government. A number of traders make supplies, charge VAT and do not report the transaction - VAWHT is an attempt to limit tax evasion (Ainsworth 2012).

However, VAWHT can lead to several problems. Waerzeggers (2008) indicates that this scheme can result in an increased VAT burden for a supplier who never has access to or uses VAT payment. They may encounter difficulty in getting a refund if the withholding leads to excess input tax credits. VAWHT can create cash flow problems for compliant firms that do not receive their excess VAT credit (Ainsworth 2012).

A number of countries in Africa have moved from Sales Tax to VAT. However, there is a lot of tax evasion and avoidance amongst VAT-registered taxpayers, and much VAT revenue is not collected. Recently this has encouraged a number of countries to introduce VAWHT, including Kenya, Ethiopia, Uganda, Zambia and Zimbabwe. This research may encourage other African and other developing countries to introduce VAWHT, and revenue authorities

1 Fiscalisation refers to configuring of fiscal devices to enable them to record sales and other tax information on the readonly fiscal memory at the time of sale, for use by the Zimbabwe Revenue Authority (ZIMRA) in VAT administration. 
may use the results to increase the number of VAWHT agents who can collect VAWHT and VAT on behalf of the government.

While VAWHT is perceived as a good tax policy by both taxpayers and tax administrators, there are challenges in tax administration associated with its introduction. This paper sheds light on the implications of VAWHT policy for taxpayers and administrators - how they both perceive VAWHT policy, and what can be done to improve VAWHT administration, including additional training and further research on the part of tax administrators, VAWHT agents and suppliers.

\section{Literature review}

Value added tax is a multi-staged tax that is charged on the value added to any services when they are rendered and goods as they go through different stages of production and distribution (James 2015). A number of developing countries moved to a VAT system from sales tax because of the perceived intrinsic advantage in the collection process (Gerard and Naritomi 2018).

VAT is a broad-based tax on the supply of goods and services, with systematic crediting of the tax paid on inputs. Since the introduction of VAT in France in 1948, it has spread around the world and been adopted in more than 160 countries around the world. It raises an average of 20 per cent of the total tax revenue collected in OECD countries and worldwide (UNCTAD 2018). VAT has been introduced in many countries in Africa. ${ }^{2}$ The international spread of VAT is due to various factors, including its potential to raise tax revenue when it is properly designed and administered (EPS-PEAKS 2013). Additional reasons for the spread of VAT include broadening the tax base, making tax systems fairer, and reducing the burden of personal income taxes.

VAT has contributed greatly to total revenue in sub-Saharan Africa (SSA). Figure 1 shows that VAT contributes more to total revenue in SSA countries than in EU countries.

\section{Figure 1 VAT contribution to total revenue in SSA and EU}

\section{VAT revenue as $\%$ of total revenue}

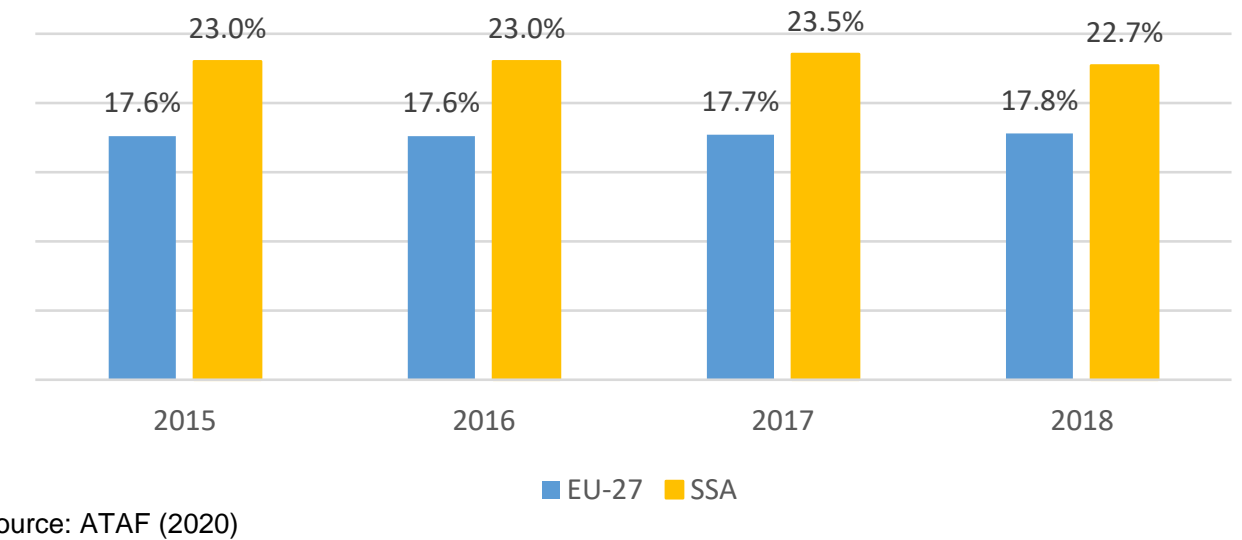

Source: ATAF (2020)

Michael Keen (2007) notes that VAT is simply too easy a way for a government to raise revenue. Introducing VAT would lead to higher total tax collection over time, and facilitate the

Zimbabwe, South Africa, Kenya, Madagascar, Ghana, Guinea, Mauritius, Niger, Nigeria, Senegal, Tanzania, Togo, Uganda Benin and Cote d'Ivoire. 
development of a larger federal government. In other words, VAT would be a money machine. Proponents of VAT have traditionally used this as a central argument in favour of the tax, claiming that it is usually less distortionary and a practicable way of raising revenue.

However, in some cases there are technical reasons that prevent transactions being brought into tax. It is not easy, for example, to allocate the value added in the provision of financial services between buyer and seller in such a way as to ensure proper functioning of the crediting mechanism. Costs of administration and compliance may warrant excluding some perfectly honest traders from VAT.

Taxation imposes various costs on the private sector including hidden costs arising from the levying and collection process - known as the compliance costs of taxation. The operating costs of taxation comprise compliance costs plus the tax authority's administration costs - or collection costs - that are incurred by the tax authority in administering an existing tax code.

The relationship between administrative costs and compliance costs is particularly important. They may be complementary or in competition with each other. With the former, measures to simplify tax may lead to a reduction in both administrative and compliance costs. With the latter, some tasks may be transferred from the tax authority (public sector) to the taxpayer or third party (private sector). Administrative costs would then be relatively lower, and compliance costs relatively higher. The reverse situation - a transfer of costs from the taxpayer to the tax authority - could also occur, but is less likely (Lymer 2002).

VAT can actually reduce efficiency, for it clearly has potential weaknesses. When the VAT chain is broken, as often happens for many reasons, production inefficiencies may be created. These could in principle offset the benefits of greater assurance of revenue collection (Keen and Lockwood 2007). VAT has also proved vulnerable to high-profile attack from criminals - such as 'carousel fraud', which exploits arrangements for the taxation of intra-community trade within the EU, amounting to 1.5-2.5 per cent of net revenue in the United Kingdom (Keen and Smith 2007). Imperfections in the refund system, and/or excessive statutory exemptions, may have meant that VAT has in practice functioned largely as a tax on exports and intermediate production, and so tended to reduce exports and national output.

In Rwanda many have experienced delays and even failure to process legitimate refunds, with participants saying that it takes a lot of time, almost a year, and is not convenient for businesses. Firms appear to prefer a predictable cash flow to waiting for an uncertain refund of the money that they are owed (Mascagni et al. 2021). This experience is confirmed in available data on refunds from the World Bank's Doing Business database. While the law provides for a 30-day limit to process refunds, or a maximum of 3 months when additional checks are needed, in practice the average time to obtain a VAT refund in Rwanda is 39 weeks - about 10 months (World Bank 2019). Rwanda, like many other low-income countries, consistently scores very weakly on the 'adequacy of refund processing' in a recent TADAT assessment (Mascagni et al. 2021).

VAWHT is a system that comprehends the declaration of VAT by both the customers and the suppliers (Ncube 2020). Withholding VAT is a tax deducted at source by the withholding VAT agent on purchase or procurement of taxable goods and services (KRA 2013). Withholding tax is important as a tracking system for registered taxpayers who reduce their actual tax liability or evade payment of tax due on taxable goods and services. When VAWHT is deducted at source and remitted, the revenue tax authorities become aware of the transaction between the withholding agent and the taxpayer. The tax withheld becomes a basis for the remaining VAT to be expected (Sibanda and Mbuyisa 2020). 
The registered taxpayer is obliged to pay the balance after matching the actual tax liability against the tax withheld when they are submitting their VAT return and payments.

The VAWHT system can lead to confusion among taxable persons who consider that they are freed from further VAT obligations when VAT has been withheld by their clients, and who thus fail to subsequently declare the taxable supplies they have made (Mugisha 2018). VAT withholding schemes encourage significant abuse on the part of the withholders, including delays in payment of VAT withheld (Fossat and Bua 2013). Withholding agents fail to remit withheld VAT to the treasury, often considering the withheld amount to be compensation for their own outstanding excess input tax credits or other claims on the treasury (PWC 2019). Finally, the withholding regime adds a layer of administrative complexity for taxable persons, withholding agents and the tax administration.

Waerzeggers (2008) further notes that, while comprehensive withholding systems bolster revenue collection in the short term, these gains may be lost in the long run - proving the system to be less convincing. These systems do not appear to be an appropriate proxy for effective and efficient management, control and recovery of VAT. VAWHT agents do not want to bear the extra VAT themselves, so they try to pass it on to the supplier by reducing the price paid (Mugisha 2017). This means that (unregistered) suppliers receive a lower price if they sell to the formal sector when their trading partners are agents. They have no incentive to sell to the VAWHT agents, and would rather find an alternative buyer who will pay a higher price (since no VAT is withheld). VAWHT agents then end up either paying higher prices than their competitors, or losing out on supplies. In this way, VAWHT can distort the market.

In general, although opinions on VAWHT differ, there appears to be consensus that the proliferation of such schemes can seriously undermine the integrity and long-term health of VAT (International Tax Dialogue 2005), and that VAWHT schemes are not compatible with modern VAT (Fossat and Bua 2013). VAWHT agents must register with the tax administration, issue vouchers at the time of withholding the tax, and file a declaration of withheld VAT.

The best way to deal with VAT compliance problems in the small business sector is to regulate the number of registered taxpayers by adopting an appropriate VAT threshold. Most suppliers and VAWHT agents want government contracts and tenders. The best approach to government contracts is to develop effective exchanges of information, and to remove businesses that fail to comply with their VAWHT obligations from the list of eligible government suppliers (Brondolo and Zhiyong 2017). This will promote effective withholding of VAT and improve VAT revenue collection.

Many developing countries have adopted a withholding tax scheme to combat sales and profit tax evasion by small firms and the self-employed. While withholding tax, in principle, does not change tax liability of firms, it can improve revenue collection in economies that have widespread evasion and a low level of compliance, or non-filing firms (Brockmeyer and Hernandez 2016). Like the third-party information report, information provided by withholding tax agents can be used to improve compliance with VAT and corporate income tax. The default payment mechanism of a withholding tax scheme in increasing VAT revenue collection (Brockmeyer and Hernandez 2016), in particular, could also be applicable for corporate income tax.

A number of countries that have introduced a VAT system have gained a more effective tax instrument, but this is less noticeable in developing countries - particularly in SSA (Keen and Lockwood 2007). Due to the amount contributed by VAT to total revenue there is a need to 
safeguard VAT revenue collection, and evaluate whether the introduction of value added withholding tax is effective in developing countries.

The withholding VAT (WHVAT) system in Kenya was initially introduced in 2004. Upon its introduction, designated WHVAT agents were required to withhold 100 per cent of VAT on paying suppliers and remit it directly to KRA. However, due to numerous challenges posed by the system at the time, the government repealed this in 2014. These challenges included large VAT refund claims being due to suppliers who were in a VAT refund position owing to the withheld VAT, certain WHVAT agents not remitting the tax withheld to the KRA, WHVAT agents delaying the issue of withholding tax credit certificates to suppliers, and suppliers failing to provide supporting documentation for WHVAT refund claims (KRA 2016).

The Government of Kenya re-introduced the WHVAT system in 2016, once the iTax electronic tax system had been fully rolled out. This has addressed some of the administrative challenges that WHVAT initially posed to taxpayers. The system continues to lead to critical cash flow challenges for suppliers who have to pay KRA the total output VAT without the right to offset the withheld VAT against their output tax, since tax credit certificates are not issued on a timely basis (KRA 2016).

In 2019 , domestic VAT in Kenya grew by 12.3 per cent, driven by 9.8 per cent growth in value added tax turnover; this was mirrored in nominal GDP growth of 10.4 per cent. The domestic VAT growth was also explained by growth in WHVAT, and in particular growth in public sector withholding, which grew by 12.1 per cent (KRA 2019). Similarly, countries like Zambia and Uganda are currently using VAWHT as a means of tackling tax evasion. VAT revenue started to increase after the introduction of VAWHT in both countries.

According to Ainsworth (2011), Cameroon abolished its VAT withholding scheme in January 2010. Later, however, deduction of VAT at source was compulsory for all supplies to public bodies. Cameroon reintroduced its VAWHT system in 2011 - IMF (2011) reveals that key measures included in the Cameron budget and are currently being implemented include restoring VAWHT at source procedures. Tax authorities publish the list of exporters entitled to withhold VAT.

In Nigeria, government and government agencies, and oil and gas companies, including oil service companies, are required to withhold VAT at source from all goods on which VAT is charged. (FIRS 2019).

In Senegal the VAT withholding system was abolished in 2013. IMF (2015a) notes shortfalls in VAT revenue following the abolition of VAT withholding by public agencies in Senegal after the 2013 reform of the General Tax Code. Exporters subject to VAT, and who realise more than 80 per cent of their sales transactions abroad, have to withhold VAT paid. A recent survey of countries where a VAT withholding system has been implemented shows almost all have very low VAT registration thresholds (International Tax Dialogue 2005).

A number of countries, particularly those in Latin America and Africa, are currently operating a VAT withholding scheme (IMF 2015a). A number of African countries introduced VAT withholding schemes to improve VAT revenue collection throughout the 1990s. Latin American countries with VAT withholding scheme include Ecuador, Colombia, Panama and Mexico (IMF 2015b). As IMF (2007) notes, the lack of a registration threshold in several Latin American countries has often led to the adoption of VAWHT systems to offset the difficulties of administering VAT owed by small and micro enterprises. 


\section{Zimbabwe}

Value added tax (VAT) was introduced in Zimbabwe in 2004. In Zimbabwe VAT is a transaction tax. Some transactions, such as all luxury goods and entertainment, are taxed at a standard rate of 14.5 per cent (effective 1 January 2020; previously 15\%); exports and basic food stuffs, for example, are taxed at a rate of 0 per cent; ${ }^{3}$ other transactions, such as financial services, provision of electricity for domestic use, provision of piped water for domestic use and rates charged by local authorities, are exempt from VAT. ${ }^{4}$ Input tax deductions may be claimed, subject to certain provisions. Advice on the implications of VAT for specific transactions related to corporate operations should be obtained prior to execution of transactions. The registration threshold has been increased to an annual turnover of RTGS $\$ 4.8$ million, (from RTGS $\$ 60,000$, which was unadjusted from US\$-based currency).

VAT is levied on every taxable supply by a registered person - any supply of goods or services in the course or furtherance of a taxable activity. A taxable activity means any activity that is carried on continuously or regularly in Zimbabwe that involves the supply of goods or services for consideration. VAT is payable on all imports for local consumption into Zimbabwe, subject to certain exemptions (e.g. in terms of a technical assistance agreement, donations to the state, and goods of which the local supply is zero-rated). Import VAT is payable on the import value plus the applicable customs duty. This is generally payable in the currency that was paid for the goods imported.

A registered VAT vendor is entitled to deduct input tax credits paid in the course of taxable supplies made to such persons, provided that a tax invoice is available to support the input tax deduction. It is also important to take note of deemed input tax deductions and prohibited input deductions. Import VAT paid may only be deducted as input tax if the import was in furtherance of a taxable activity and the required documentation (e.g. stamped customs entries) is held by the importer. VAT returns are due by the $25^{\text {th }}$ day following the month to which the VAT relates. All large clients file VAT returns monthly, and small and medium clients file VAT returns every two months. It is mandatory for all registered taxpayers (everyone that has a tax Business Partner Number) to use electronic fiscal registers (EFRs) that can be linked to the Zimbabwe Revenue Authority (ZIMRA). Penalties of up to US\$25 per day per point of sale may be imposed. With effect from 1 January 2019, where sales of goods or services are effected in foreign currency, the VAT operator must account for the related VAT in the same currency.

VAWHT was introduced in Zimbabwe in September 2016 to improve VAT revenue collection. ${ }^{5}$ ZIMRA, in terms of Section $50 A$ of the VAT Act, appointed 78 large registered operators, mainly mining companies, as VAWHT agents with effect from 1 January $2017 .{ }^{6}$

\footnotetext{
The government does not tax the retail sale of a zero-rated good, but allows credits for the VAT paid on inputs. The government does not tax the sale of a good or business that is exempt, but producers cannot claim a credit for the VAT they pay on inputs to produce it. https://www.zimra.co.zw/news/2125:value-added-tax-withholding-tax.

Ashanti Goldfields Zimbabwe Ltd, Trojan Nickel Mine Ltd, Afrochine Smelting (Pvt) Ltd, Blanket Mine (1983) (Pvt) Ltd, Xin Yu Mining Corporation (Pvt) Ltd, Falcon Gold Zimbabwe (Pvt) Ltd, Well Mining (Pvt) Ltd, Niarchos Investments (Pvt) Ltd, Bulawayo Mining Company Ltd, Goldfields of Shamva (Pvt) Ltd, Goldfields of Shamva (Pvt) Ltd, The King's Daughter Mining Company (Pvt) Ltd, Mimosa Mining Company (Pvt) Ltd, Murowa Diamonds (Pvt) Ltd, Unki Mines (Pvt) Ltd, Zimasco (Pvt) Ltd, Zimbabwe Platinum Mines (Pvt) Ltd, RioZIM Limited, Pan African Mining (Pvt) Ltd, Forbes and Thompson (Pvt) Ltd, Bikita Minerals (Pvt) Ltd, Mohammed Musa Wholesalers (Pvt) Ltd, N. Richards and Company Masvingo, TM Supermarkets P/L, Ok Zimbabwe P/L, Padenga Holdings Ltd, Beta bricks P/L, Willdale (Pvt) Ltd, Lafarge Cement Ltd, PPC Zimbabwe Ltd, Blue Ribbon Foods (Pvt) Ltd, National Foods Ltd, Profeeds (Pvt) Ltd, Novatek Animal Feeds (Pvt) Ltd, Parrogate Zimbabwe (Pvt) Ltd, Zimbabwe Power Company, ZESA Holdings, Zimbabwe Electricity Transmission and Distribution Company [ZETDC], Delta Beverages (Pvt) Ltd, Econet Wireless (Pvt) Ltd, Net One Cellular (Pvt) Ltd, Telecel Zimbabwe (Pvt) Ltd, Dairibord Zimbabwe (Pvt) Ltd, Cairns Foods (Pvt) Ltd, Powerspeed electrical (Pvt) Ltd, Zimkings Trading (Pvt) Ltd, Picktalk Investments (Pvt) Ltd, N Bhadella and Sons, British American Tobacco Zimbabwe, Schweppes Zimbabwe (Pvt) Ltd, Applebridge Investments (Pvt) Ltd, Corundum Mining Company, Natural Stone Export Company, RHA Tungsten (Pvt) Ltd, Zimbabwe German Graphite Mines, Southern Granites( Pvt) Ltd., Quarrying Enterprises (Pvt) Ltd, Newtron Mining (Pvt) Ltd, Kadoma Magnesite (Pvt) Ltd, Jin An
} 
The main obligations of VAWHT agents are to:

- Withhold one-third of the output tax from each amount to be paid to a specified operator (supplier of goods or services to the appointed agents) of taxable goods and services. The amount to be withheld was initially introduced as two-thirds of output tax in January 2017 and was then revised to one-third of output tax in January 2018.

- Submit VAWHT returns and remit the amounts withheld to ZIMRA on or before the $15^{\text {th }}$ day of the following month. A schedule of VAWHT should be attached to the return.

- Issue a VAWHT certificate to such supplier in respect of the amount withheld.

Where a taxpayer makes a taxable supply and has issued a proper tax invoice, VAWHT is calculated based on guidelines of the revenue authority. The VAWHT rate applicable in Zimbabwe is currently at one-third of output tax charged (ZIMRA 2021).

VAT withheld by an agent does not relieve the supplier, who is the taxable person, from the obligation to charge VAT at the standard rate of 14.5 per cent. The supplier is still obliged to file monthly or bi-monthly returns, and to pay the balance of two-thirds - to make a total of 14.5 per cent - on the $25^{\text {th }}$ day of the following month after the end of the tax period, in accordance with the relevant provisions of the VAT Act (ZIMRA 2021).

\section{Research methodology}

The objective of this study is to assess the perspective of taxpayers and tax administrators on value added withholding tax policy in Zimbabwe. The aim was to gather information on agents' and suppliers' perceptions of VAWHT policy. The purpose was to increase muchneeded VAT revenue, and to find out what can be done to improve VAWHT administration. The study used both quantitative and qualitative methods.

The research focus was to answer the following questions:

- 'How do taxpayers and administrators perceive the VAWHT policy?',

- 'How is VAWHT administered and what are the challenges associated with its introduction?', and

- 'Why is it important to administer this tax head'?

The quantitative aspect of the study consisted of a survey of VAWHT agents and suppliers who are VAT-registered in Harare, Zimbabwe. The researcher also focused on revenue officers from the ZIMRA VAT section and VAT-registered operators from the Large Clients Office, because these are mainly the VAWHT agents and most of them are VAT-registered. To get balanced research on the perception of agents about the introduction of VAWHT, questionnaires were sent to all 78 VAWHT agents, and 73 responded. Questionnaires were distributed to 150 suppliers who are VAT-registered operators, and 136 responded - mainly VAT registered operators who deal with mining companies and other VAWHT agents. The suppliers included medium and large clients. Some suppliers did not have employees with

Corporation (Pvt) Ltd, Inducon Investments (Pvt) Ltd, llford Services (Pvt) Ltd, Innscor Distribution (Pvt) Ltd, Comox Trading (Pvt) Ltd, Eagle Agencies (Pvt) Ltd, Tevason Investments (Pvt) Ltd t/a Freshpro, Equip Solutions (Pvt)Ltd, FMCG Distribution (Pvt) Ltd, Exclusive Brands (Pvt) Ltd, Viative Trading (Pvt) Ltd, Bullred Farming,Brands Africa (Pvt) Ltd, Brands Fresh (Pvt) Ltd, Aeromat [Cheeseman] (Pvt) Ltd, The Cold Chain (Pvt) Ltd, Harrison \& Hughson Agencies,Seedex Enterprises (Pvt) Ltd. 
enough VAWHT knowledge, and some questionnaires were emailed to an organisation's tax consultancy. Questionnaires were sent to 150 revenue administrators at ZIMRA, and 142 were fully completed. The data was collected from tax administrators who are based at ZIMRA Harare Large Clients Office and Audits section.

The structured survey included questions about respondent's characteristics, the implications of VAWHT policy on taxpayers and tax administrators, and what can be done to improve VAWHT administration in order to continuously improve VAT revenue collection. The questionnaire largely used a five-point Likert scales to identify perceptions, attitudes and opinions of varying strength. The five-point Likert scale ranged from 1 - Strongly disagree (SD), 2 - Disagree (D), 3 - Neutral (N), 4 - Agree (A) and 5 - Strongly agree (SA). A set of questions were presented in writing to VAWHT agents, suppliers and tax administrators in order to obtain detailed response of the participants on VAWHT system. Both questionnaires for ZIMRA and VAWHT agents had eight questions, and the one for suppliers had eleven questions. The questionnaires were sent by email, due to the Covid-19 pandemic and World Health Organisation requirements. The researcher obtained email addresses and contact details of the suppliers and agents from ZIMRA E-Service portal. In the covering email the researcher explained the survey, and asked identified participants to complete it.

In-depth interviews were conducted online through Zoom and Teams meetings and over the telephone with VAWHT agents, suppliers, and tax administrators from ZIMRA who had responded to the questionnaires. Some other taxpayers and administrators were invited to the interviews in groups so as to have more of a discussion on VAWHT policy. The main purpose of the interviews was to understand the perception of taxpayers and tax administrators, the challenges of administering VAWHT, and what taxpayers and administrators think can be done to improve the policy so it can fulfil its purpose of improving the collection of much-needed VAT revenue. The interviews helped the researcher to understand the responses on the questionnaires.

The paper checked the performance of VAT revenue collection before and after the introduction of VAWHT in 2017. Internal administrative data from ZIMRA was analysed to show the extra VAT revenue that was generated after the introduction of VAWHT. The researcher collected VAWHT and VAT revenue data from relevant departments at ZIMRA. ZIMRA revenue performance reports, Ministry of Finance budgets and mid-term fiscal policy reviews were used to compile the revenue data.

\section{Data presentation}

\subsection{Responses from ZIMRA}

This section gives a summary of the data collected from revenue officers at ZIMRA. One of the requirements to be a ZIMRA revenue officer is that you have a degree in tax law, fiscal studies, economics or equivalent as a minimum qualification, so all respondents were at least a holder of a bachelor's degree. The respondents had a lot of knowledge on the area of study since they deal with VAT-registered operators and VAWHT agents on a daily basis. The majority of the revenue officers had been working for ZIMRA for at least five years. 
Figure 2 Responses from ZIMRA revenue officers

\begin{tabular}{|c|c|c|c|c|c|}
\hline & $\mathbf{N}$ & Minimum & Maximum & Mean & Std. deviation \\
\hline VAWHT improved revenue collection & 142 & 1.00 & 5.00 & 3.8169 & 1.00085 \\
\hline VAT clients are adequately trained & 142 & 1.00 & 5.00 & 2.3662 & 1.41661 \\
\hline $\begin{array}{l}\text { Legislation governing VAWHT } \\
\text { administration is sufficient }\end{array}$ & 142 & 1.00 & 5.00 & 2.7254 & 1.30544 \\
\hline VAWHT rate fair & 142 & 1.00 & 5.00 & 3.4437 & 1.31831 \\
\hline $\begin{array}{l}\text { There are adequate administration } \\
\text { procedures for successful } \\
\text { implementation of VAWHT }\end{array}$ & 142 & 1.00 & 5.00 & 2.6127 & 1.36755 \\
\hline $\begin{array}{l}\text { VAWHT affect the supplier- customer } \\
\text { relationship }\end{array}$ & 142 & 1.00 & 5.00 & 3.8310 & 1.01038 \\
\hline The VAWHT system is effective & 142 & 1.00 & 5.00 & 3.3239 & 1.20607 \\
\hline $\begin{array}{l}\text { VAWHT increased the cost of VAT } \\
\text { collection }\end{array}$ & 142 & 1.00 & 5.00 & 2.6197 & 1.23042 \\
\hline Valid N (listwise) & 142 & & & & \\
\hline
\end{tabular}

Source: Primary data

The results from questionnaires sent to ZIMRA showed that tax administrators believe the introduction of VAWHT has improved VAT revenue collection as it has reduced VAT revenue evasion. The interviews also showed that even during the Covid-19 period, when there was a shutdown and ZIMRA could not conducts audits, VAT-registered operators and VAWHT agents continued to comply, since agents were helping ZIMRA to make sure that VATregistered companies remit VAT revenue. VAT clients are not adequately educated, trained or informed about VAWHT matters, as shown by mean average of 2.37 - this is the lowest score amongst all factors, hence there is a gap in terms of taxpayer education. The interviews showed that ZIMRA holds a number of seminars and training sessions, but only a few selected taxpayers are invited to these. There is need to improve the legislation governing VAWHT, as a number of revenue officers did not believe that the legislation was enough. Follow up interviews showed that the legislation is not clear on what will happen if the appointed agent does not withhold VAT on behalf of the government. This has led to the policy not being fully implemented in Zimbabwe. ZIMRA officers perceive the VAWHT rate of one-third of the output tax charged as fair, since it is in the same range as other countries, such as Kenya, Zambia and Uganda. The tax administrators also believed that the rate of two-thirds of VAT amount when VAWHT was introduced was too high, and seriously affected the cash flow of VAT-registered operators.

The administration procedures at ZIMRA are not adequate - the results showed an average of 2.61, which is the second largest average. Most of the activities cannot be done online, the ZIMRA website is not updated continuously, and taxpayers are not always engaged when the policy is being formulated. The tax administrators also responded that VAWHT affects the supplier-customer relationship, as most suppliers complain that VAWHT agents do not issue withholding tax certificates to them on time. The failure by agents to issue certificates on time means that VAT-registered operators are not able to claim VAT withheld by agents, and this reduces the cash flow of the registered operators. In practice registered operators end up paying VAT twice, since they are not able to claim their VAT amount.

ZIMRA tax administrators perceive VAWHT as an effective tax policy, even though it is associated with a number of challenges and needs to be improved. The revenue administrators think that the policy improved compliance and tax revenue collection, since 
they now find it easy to identify VAT evaders. Tax administrators are neutral about the cost of collection, since a number think that the policy increases administrative work for taxpayers; others argued that tax administrators now need to reconcile VAWHT returns (Rev 5 return) and VAT returns (VAT 7 return) in order to identify evaders and those who are not complying with fiscal laws. Therefore the policy has relatively increased administrative cost on both parties - taxpayers and tax administrators - but with the effect of increasing compliance.

\subsection{Responses from VAWHT agents}

This section gives a summary of data collected from the VAWHT agents. The individuals who took part in this study were public tax accountants, chartered accountants and qualified tax personnel who possess sufficient knowledge about the administration of VAWHT. In Zimbabwe the majority of companies have offices in Harare, therefore the questionnaires were emailed to the responsible persons at the Harare office.

Figure 3 Responses from VAWHT agents

\begin{tabular}{|c|c|c|c|c|c|}
\hline & $\mathbf{N}$ & Minimum & Maximum & Mean & Std. deviation \\
\hline Knowledge on VAWHT & 73 & 1.00 & 5.00 & 2.8356 & 1.32302 \\
\hline Adequately trained on VAWHT & 73 & 1.00 & 5.00 & 2.6301 & 1.39947 \\
\hline VAWHT is fair & 73 & 1.00 & 5.00 & 3.6438 & 1.07199 \\
\hline $\begin{array}{l}\text { VAWHT affects the supplier- customer } \\
\text { relationship }\end{array}$ & 73 & 1.00 & 5.00 & 3.6027 & 1.23311 \\
\hline VAWHT system is effective & 73 & 1.00 & 5.00 & 3.5205 & 1.11939 \\
\hline $\begin{array}{l}\text { VAWHT system increase administration } 7 \\
\text { costs }\end{array}$ & 73 & 1.00 & 5.00 & 3.6575 & .98910 \\
\hline VAWHT system improves VAT revenue 7 & 73 & 1.00 & 5.00 & 3.8356 & .85006 \\
\hline $\begin{array}{l}\text { Suppliers prefers customers who are } \\
\text { not VAWHT agents }\end{array}$ & 73 & 1.00 & 5.00 & 3.8493 & .84445 \\
\hline Valid N (listwise) & 73 & & & & \\
\hline
\end{tabular}

Source: Primary data

The results from the agents showed that some of them have a lot of knowledge and are well educated, equipped and trained about VAWHT - especially those who are clients of the big four accounting firms. ZIMRA always invites these VAWHT agents to seminars and conferences. The tax practitioners from the big four accounting firms are amongst the few that are consulted when these tax policies are being introduced - they understand tax policy, its weaknesses and challenges. There are some who are not as well informed about VAWHT, since VAT is amongst difficult tax heads to administer.

A larger proportion of the agents think that the rate of one-third of the output tax is fair, mainly because they are the ones keeping it on behalf of the revenue authority. The policy seems to be favourable to VAWHT agents, since VAWHT agents no longer pay the full amount when they purchase goods and service because they withhold VAWHT. This is different to what was happening before the introduction of VAWHT policy. The agents withheld the amount and remit it to ZIMRA on the $15^{\text {th }}$ of the next month after the end of the tax period. Other agents are of the opinion that the tax rate is a bit high since VAWHT agents are not exempted from the tax policy, therefore they are equally affected in terms of cash flows and other challenges that come with the VAWHT policy. 
The results show that most respondents agree that the relationship between agents and customers was affected by the introduction of the VAWHT policy. The reason for this is that there is too much administrative work for the agents, and sometimes they end up not issuing withholding certificates on time. This has led to a number of VAT-registered companies preferring to do business with clients who are not VAWHT agents. However the majority view the system as an effective way to reduce evasion and maximise government revenue. Before the introduction of VAWHT tax administrators were not able to identify transactions as quickly as now, and VAT withholding tax will help ZIMRA to identify transactions.

The VAWHT agents argued that the system increases administration costs, since they are now supposed to issue withholding tax certificate and submit withholding tax returns on the $15^{\text {th }}$ of every month. The agents are VAT-registered, therefore they have to submit two returns in a period of ten days - the VAWHT return on the $15^{\text {th }}$ and VAT return on the $25^{\text {th }}$. The VAWHT agents now need to employ more personnel to be responsible for the extra administration work, and this is an extra cost for the agents. The agents believe that VAWHT policy increases government revenue at the expense of agents, as most suppliers prefer customers who are not VAWHT agents in order to safeguard their cash flow.

\subsection{Responses from suppliers}

This section gives a summary of data collected from suppliers. The researcher distributed questionnaires to suppliers who are mainly based in Harare.

Figure 4 Responses from suppliers

\begin{tabular}{|c|c|c|c|c|c|}
\hline & $\mathbf{N}$ & Minimum & Maximum & Mean & Std. deviation \\
\hline Knowledge on VAWHT issues & 136 & 1.00 & 5.00 & 2.0956 & 1.37102 \\
\hline Trained on VAWHT & 136 & 1.00 & 5.00 & 2.1912 & 1.40641 \\
\hline VAWHT fair & 136 & 1.00 & 5.00 & 1.9853 & 1.27648 \\
\hline $\begin{array}{l}\text { VAWHT affect the supplier- customer } \\
\text { relationship }\end{array}$ & 136 & 1.00 & 5.00 & 4.1029 & 1.21886 \\
\hline VAWHT system is effective & 136 & 1.00 & 5.00 & 3.6250 & 1.40337 \\
\hline $\begin{array}{l}\text { VAWHT negatively affects Suppliers } \\
\text { cash flows }\end{array}$ & 136 & 1.00 & 5.00 & 4.4191 & 1.15184 \\
\hline $\begin{array}{l}\text { VAWHT has minimised VAT non- } \\
\text { compliance }\end{array}$ & 136 & 1.00 & 5.00 & 3.5662 & 1.20310 \\
\hline $\begin{array}{l}\text { VAWHT system has put a stop hold } \\
\text { on VAT evasion }\end{array}$ & 136 & 1.00 & 5.00 & 3.6029 & 1.21886 \\
\hline $\begin{array}{l}\text { VAWHT agents' delays issuance of } \\
\text { withholding tax credit certificates }\end{array}$ & 136 & 2.00 & 5.00 & 4.2721 & 1.07818 \\
\hline $\begin{array}{l}\text { Suppliers provide enough support } \\
\text { documentation in relation to VAWHT } \\
\text { refunds }\end{array}$ & 136 & 1.00 & 5.00 & 3.7059 & 1.16821 \\
\hline ZIMRA pays refunds on time & 136 & 2.00 & 5.00 & 4.5294 & .94235 \\
\hline Valid N (listwise) & 136 & & & & \\
\hline
\end{tabular}

Source: Primary data

The results from the suppliers showed that most lack knowledge about the VAWHT system, and a number of suppliers are not well trained, educated or informed. This is because ZIMRA only engages with the big clients who happen to be VAWHT agents when they are hosting 
training sessions and seminars. Most of the suppliers are left out and they are not well informed or trained on VAWHT matters.

The government policymakers did not take into consideration a number of suppliers' contributions when the new tax policy was being introduced. Suppliers are of the opinion that the VAWHT rate of one-third of VAT output tax charged is not fair, as it negatively affect their cash flows. VAWHT agents now withhold an amount that suppliers used to keep for at least a month, up to a maximum of two months, depending on the registered tax period, before VAT revenue was remitted to ZIMRA. The introduction of VAWHT policy means that this amount is no longer received by suppliers, as happened before the introduction of VATWHT.

The relationship between suppliers and VAWHT agents is no longer the same, as most agents do not issue withholding tax certificates in time for suppliers to be able to claim their VAT refunds from ZIMRA. Some suppliers argued that they do not want to accept withholding tax certificates as a form of payment. This has led to a distortion of the business relationship between suppliers and agents. Tax policies should promote business - this is not the case with VAWHT, since its introduction has created problems between taxpayers.

Suppliers also believe that the system is effective in collecting government revenue, and has minimised VAT non-compliance amongst medium and large clients - those who mainly supply to mining companies who are VAWHT agents. In most cases suppliers cannot provide enough support documentation to claim their refunds, because VAWHT agents do not provide the documents, including withholding tax certificates, on time. This delays payment of refunds by ZIMRA. This makes the policy unattractive to a number of taxpayers.

\subsection{Zimbabwe VAT revenue performance}

Figure 5 VAT revenue performance

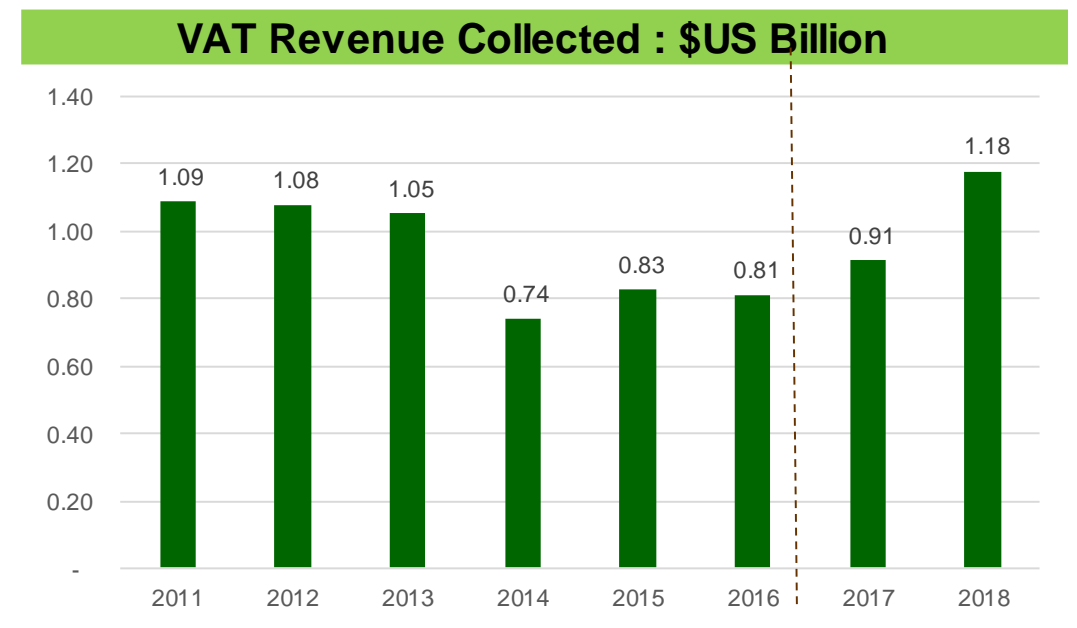

Source: ZIMRA Revenue reports 2011-2018

Figure 5 shows the VAT revenue performance in Zimbabwe before and after the introduction of the VAWHT system. VATWHT was introduced in January 2017 (the vertical line). VAT revenue collection was decreasing from 2011 , with policies such as fiscalisation and audit refunds in place. In 2016 Zimbabwe proposed to introduce a VAWHT system to improve collection of VAT revenue - this came to effect on 1 January 2017. No other system has been introduced since then to enhance VAT revenue collection. VAT revenue collection increased from US $\$ 0.81$ billion in 2016, to US $\$ 0.91$ billion in 2017 , and US $\$ 1.18$ billion in 2018. There is a need to continue safeguarding VAT revenue - since 2011 VAT revenue has 
been a major contributor to total revenue in Zimbabwe, contributing an average of 26 per cent of total revenue.

\section{Summary of major findings}

The VAWHT agents have a positive attitude towards VAWHT - VAWHT agents believe the system is fair and effective, and that the system is suitable for Zimbabwe. Most revenue officers who work in the Larger Clients Offices, who are responsible for administering VAWHT tax agents, believe that VAWHT agents are well-educated on the subject matter, which is one of the reasons why VAWHT agents also have a positive attitude towards the VAWHT system. The study also revealed that VAT registered suppliers do not have sufficient knowledge, education or training on VAWHT, mainly because most of them have not attended a single VAWHT seminar or training programme. ZIMRA is trying to enhance knowledge by conducting VAT-specific seminars, but invites the same large clients to these seminars every time.

The findings also reveal that withholding agents are facing the problem of suppliers refusing the value added withholding tax certificate as payment - this leads to suppliers not delivering, and relations being jeopardised. The suppliers and the tax official respondents noted that suppliers are now charging relatively high prices for goods and services supplied to withholding agents in a bid to reduce the impact of the amount withheld.

The tax officials noted a number of challenges. These include:

- large VAT refund claims due to suppliers who find themselves in a VAT refund position owing to withheld VAT

- some VAWHT agents not remitting tax withheld to ZIMRA

- VAWHT agents delaying issue of withholding tax credit certificates to suppliers, and

- Suppliers failing to provide supporting documentation in relation to VAWHT refund claims.

The suppliers also highlighted that VAWHT has left some suppliers with shortages of working capital. Before the introduction of the VAWHT policy, suppliers would receive a VAT amount in full and remit it to the revenue authority on the $25^{\text {th }}$ of the month after the end of the tax period. With the introduction of the VAWHT system, suppliers sometimes have to pay ZIMRA the total output VAT, without the right to offset the withheld VAT against their output tax, since VAWHT agents sometimes do not issue tax credit certificates on a timely basis. When a business makes a supply on which VAT is withheld and paid to ZIMRA in addition to the normal output VAT, it may be forced to seek additional financing for working capital for the period between payment and refund.

Most respondents (suppliers and agents) highlighted that the new VAWHT has increased the administrative burden on firms that are already failing in Zimbabwe. Rwanda is a good setting for exploring how VAT functions in practice in lower-income countries. It faces many of the challenges common to low- and middle-income countries, such as severe constraints in tax administration capacity and widespread evasion.

However, it has the relatively stable and efficient institutional setting that is a necessary condition for VAT to work (Mascagni et al. 2021). VAT imposes costs on the taxpayers who are registered for it. They need to keep a record of each transaction; aggregate such records periodically (monthly or quarterly) and send them to the tax administration; and make claims 
for inputs and back them up with appropriate records. All this represents an administrative burden for firms - or compliance cost (Mascagni et al. 2021). These requirements may put taxpayers off registering for VAT altogether (Barbone et al. 2012; Harju et al. 2019; Slemrod and Velayudhan 2020). For this reason, VAT systems usually include a turnover threshold under which firms are not required to register for VAT (Keen and Mintz 2004). This creates its own inefficiencies: a recent study shows that firms select their trading partners based on VAT registration, thus creating segmentation in the value chain (Gadenne et al. 2019).

The responses also revealed that most of the affected parties agree that VAWHT will boost government revenue at the expense of suppliers and agents. However, the literature reviewed showed that the boost in government revenue would only be in the short run, and the increase will be offset in the end due to high administration costs.

VAT withholding schemes mostly aim at mitigating non-compliance, especially among smaller businesses. However, in Zimbabwe VAWHT is being applied on relatively large businesses that supply larger taxpayers, government agencies and institutions. This approach excludes the majority of small and medium enterprises from the scheme. Similar to other countries, appointing small and medium businesses as VAWHT agents, and requiring them to withhold VAT on their supplies to other businesses, would not address the problem either, but would add another layer of complexity to the system.

The views of tax officials at ZIMRA on the revenue role of VAWHT are mixed, with most of them arguing that VAWHT increased revenue collection. Although it is important to analyse statistically the revenue contribution of VAWHT in Zimbabwe, the trend analysis shows the positive revenue performance of taxes - particularly VAT after the implementation of the VAT withholding scheme. However the VAWHT system has contributed to an increase in VAT withholding-related refund requests. This, in turn, has exacerbated the burden of VAT on tax authorities, as tax officials have to carry out full verification of the increasing number of VAT refund requests.

The difference between credit sales and payment dates was also noted as a problem in the VAWHT system, as the system requires taxpayers to pay VAT on credit sales that are subject to VAWHT at the time of payment by the buyer. Another problem is the order of offsetting net VAT payable against VAT credits brought forward from previous periods and VAWHT. With the VAWHT system, the order of offsetting net VAT payable has become an area of disagreement, as it has implications for timing of VAT refunds. VAWHT agents' failure to remit the revenue withheld to ZIMRA within the set time, and failure of legally appointed agents to withhold VAT, were also indicated as problems in the VAWHT system.

\subsection{Conclusions}

The objective of this study was to determine the perception of both taxpayers and tax administrators on the introduction of Value Added Withholding Tax policy. The study has revealed that the attitude of a taxpayer towards VAWHT largely affects their decision on compliance. The attitude of the taxpayer in this case is largely influenced by their knowledge of the system. From the findings, the research concludes that, unless suppliers are educated on the subject matter, the value added withholding tax will be less effective in its objective to curb non-compliance.

The researcher concludes that the VAWHT system is a promising idea to curb tax noncompliance and tax evasion, because it brings the merits of tax deduction at source into VAT. The VAWHT system is perceived as a good way of increasing revenue - earlier sections showed how it boosted VAT revenue from 2017. It is not an effective tax system and 
is underpinned by high administrative costs, the inconvenience of losing customers and suppliers, and poor knowledge of the system by registered VAT operators.

Whereas the intention behind the VAWHT system may be understandable, the challenges of the system cannot be ignored. The government may need to re-think certain aspects in light of the potentially significant negative impact on the cash flows of compliant taxpayers, administration costs on suppliers and agents, and the economy in general.

ZIMRA, the Ministry of Finance and all other tax policymakers need to work on the perception of the taxpayers towards VAWHT policy in order for it to be embraced and to achieve the intended objectives of the policy.

\subsection{Recommendations}

- Revenue authority should allow an exemption for compliant taxpayers (e.g. for VAT withholding agents). As these agents were appointed as they were the most compliant and largest taxpayers in the country, they should be exempted from this system as it also affects their cash flow.

- Strengthen the revenue authority refund system so the expected excess of VAT withholding is refunded in time.

- Educate and train taxpayers on the benefits of the VAWHT system, so they may be able to develop a well-informed attitude towards VAWHT.

- The revenue authority should automate the system so that as soon as the revenue authority receives information about VAT withheld they can automatically debit the supplier's account with the amount remitted by the agent, thus reducing the administrative cost.

- The revenue authority should improve the administration of VAWHT through automation so that both the appointed withholding agent and registered supplier are able to perform their VAWHT obligations, without having to rely on a tax certificate from the agent.

- Increase the number of VAWHT agents - suppliers will not have to avoid supplying goods and services to appointed VAWHT agents if there are more of them.

- Reduce the VAWHT rate from one-third of the output tax charged to maybe one quarter or one-fifth of the output tax charged, in line with other countries. The whole purpose of the VAWHT system is to know the transactions that took place between suppliers and their customers.

- Facilitate set-off where a client is both supplier and an agent.

- Allow VAWHT agents to claim administrative expenses. These should be allowed as deductions in terms of the Income Tax Act.

- Conduct more public awareness campaigns on radio stations, national television, billboards, twitter, Facebook and tax conferences, and specifically include both suppliers and agents in the awareness conventions.

- The revenue authority should increase taxpayer education to ensure that taxpayers are sufficiently educated on VAWHT issues to be aware of the mechanics of the system. The government should also introduce tax education into the education system curriculum, so that taxpayers are not completely uninformed. This will help to change the attitude of taxpayers towards new tax policies.

- The revenue authority should develop a mechanism that splits out the VAT element requiring the credit/debit card company to split the VAWHT element from the buyer's payment, and directly deposit it with the tax authorities. The key change in moving to real-time collection of VAWHT is that the tax is collected and remitted on each individual transaction at the time the customer settles payment of the transaction with the supplier. 


\section{References}

Ainsworth, R. (2012) 'Refund Fraud? Real-Time Solution!"',134 Tax Notes 1165 (27 February 2012). Republished as "Real-Time Solution to Refund Fraud: VAT Lessons From Belgium, Brazil, and Quebec" in 66 Tax Notes International 533

- (2011) VAT fraud as a Policy Stimulus - Is the Us Watching? VAT withholding, RTVAT and the Mittler Model, Working Paper No. 11-08, Boston University School of Law

Barbone, L., Bird, R. and Vazquez-Caro, J. (2012) The Costs of VAT: A Review of the Literature, s.I.: SSRN Electronic Journal

Brockmeyer, A. and Hernandez, M. (2016) Taxation, information, and withholding: evidence from Costa Rica, Policy Research Working Paper Series 7600, The World Bank

Brondolo, J. and Zhiyong, Z. (2017) Strengthening Tax Administration, Washington DC: International Monetary Fund

EPS-PEAKS (2013) Taxation and Developing Countries, EPS-PEAKS

FIRS (2019) FIRS' Public Notice on deduction of WHT and VAT at source from compensation paid to agents, dealers, Lagos: Federal Inland Revenue Service

_ (2018) Nigeria Revenue Report, Lagos: Federal Inland Revenue Service

Fossat, P. and Bua, M. (2013) Tax Administration Reform in the Francophone Countries of Sub-Saharan Africa, Washington DC: International Monetary Fund

Gadenne, L., Nandi, T. and Rathelot, R. (2019) Taxation and Supplier Networks: Evidence from India, unpublished

Gerard, F. and Naritomi, J. (2018) Value Added Tax in developing countries: Lessons from recent research, Growth Brief, International Growth Centre

Harju, J., Matikka, T. and Rauhanen, T. (2019) 'Compliance Costs vs. Tax Incentives: Why do Entrepreneurs Respond to Size-based Regulations?', Journal of Public Economics 173(C): 139-164

IMF (2015a) Current Challenges in Revenue Mobilisation : Improving Tax Compliance, Washington DC: International Monetary Fund

- (2015b) Revenue Mobilization in Developing Countries, Washington DC: International Monetary Fund

- (2011) Revenue Mobilization in Developing Countries, Policy Paper, Washington DC: International Monetary Fund

(2007) The Value-Added Tax: Its Causes and Consequences, Policy Paper, Washington DC: International Monetary Fund

International Tax Dialogue (2005) Key issues and debates in VAT, SME Taxation and the Tax treatment of the Financial Sector, International Tax Dialogue 
James, K. (2015) An introduction to the good VAT (2nd ed.), Victoria: Cambridge University Press

Keen, M. (2007) VAT Attacks!, IMF Working Papers 2007/142, International Monetary Fund

_ and Lockwood, B. (2007) The Value-Added Tax: Its Causes and Consequences, Washington DC: International Monetary Fund

_ and Mintz, J. (2004) 'The optimal threshold for a value-added tax, Journal of Public Economics, 88(3-4): 559-576

- and Smith, S. (2007) VAT Fraud and Evasion: What Do We Know, and What Can be Done?, Washington DC: International Monetary Fund

KRA (2019) Annual Revenue Perfomance 2018/2019, Nairobi : Kenya Revenue Authority

— (2016) Kenya Revenue Report, Nairobi: KRA

— (2013) Revenue Report, Nairobi: KRA

Lymer, A. and Hasseldine, J. (eds) (2002) The International Taxation System, Kluwer Academic Publishers

Mascagni, G., Dom, R. and Santoro, F. (2021) The VAT in practice: equity, enforcement and complexity, ICTD Working Paper 117, Brighton: Institute of Development Studies

Mugisha, D. (2018) Withholding VAT - Plugging the revenue gap - here comes withholding VAT, Kampala: PWC

Ncube, M. (2020) 2021 Zimbabwe Fiscal Budget, Harare: Minstry of Finance

PWC (2019) Tax Data Card Nigeria, Lagos: PWC

Slemrod, J. and Velayudhan, T. (2020) The VAT at 100: A Comprehensive Health Assessment, With a Plan of Care and Suggestions for Diagnostic Tests, unpublished

Sibanda, V. and Mbuyisa, A. (2020) Global tax guide to doing business in Zimbabwe, Dentons

Waerzeggers, C. (2008) VAT in Africa, Richard Krever, ed. 2008

World Bank (2019) Doing Business 2020: Rwanda, Washington DC: The World Bank

ZIMRA (2021) Revenue Report. Harare: ZIMRA

ZRA (2018) Zambia Revenue Report, Lusaka: ZRA 